\title{
Online teaching during COVID19 pandemic in different medical Institutions of West Bengal- From student's perspective
}

\author{
Bhaskar Saha', Mrityunjoy Halder², Mita Mandal ${ }^{3}$, Subir Kumar Das ${ }^{4}$ \\ ${ }^{1}$ Assistant Professor, Department of Physiology, College of Medicine and JNM Hospital, Kalyani, West Bengal -741235, \\ ${ }^{2}$ Assistant Professor, ${ }^{4}$ Professor, Department of Biochemistry, College of Medicine and JNM Hospital, Kalyani, West \\ Bengal -741235, ${ }^{3}$ Assistant Professor, Department of Orthodontics \& Dentofacial Orthopaedics, Guru Nanak Institute of \\ Dental Science \& Research, Kolkata, West Bengal- 700114
}

Background: Social distancing is important preventive strategy to prevent spreading of SARSCOV-2. The medical faculties are continuing the teaching-learning session using different online platform. Aims and Objective: This online survey aims at exploring the different aspect of online teaching effects among medical students. Materials and Methods: Forty-four validated questions in the Google survey form were distributed among the MBBS students of different medical colleges of West Bengal in this cross-sectional study, and analysed. Results: The responses from 416 participants show that internet-based teaching has been adopted by $96.4 \%$ of colleges. Practical class and classes regarding clinical exposure are the two most neglected section of the MBBS curriculum during this pandemic. Total teaching hours per day also drastically reduced from mean of $5.56 \mathrm{~h} /$ day in pre-pandemic time to $1.95 \mathrm{~h} /$ day during this pandemic. Out of $69.7 \%$ of the participants who faced difficulty in following online classes, majority $(56.25 \%)$ was due to technical problems including issues related to internet connectivity and software. Participants were of opinion that current session should be extended on an average of 3 months as the practical and clinical classes are way behind in syllabus completion. According to $72.35 \%$ of participants, online classes are less effective than the offline classes. Conclusions: In nutshell, online teaching activities cannot replace the classical classroom teaching, though it is a cost-effective and viable method during this pandemic period.

Key words: COVID-19; Online teaching; Medical education; MBBS
Access this article online

Website:

http://nepjol.info/index.php/AJMS

DOI: 10.3126/ajms.v12i7.35203

E-ISSN: 2091-0576

P-ISSN: 2467-9100

Copyright (c) 2021 Asian Journal of Medical Sciences

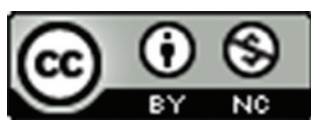

This work is licensed under a Creative Commons Attribution-NonCommercial 4.0 International License.

\section{INTRODUCTION}

In late 2019 multiple cases of severe pneumonia of unknown cause were reported from the Wuhan city of Hubei province of China. The causative agent was soon identified by genomic sequencing as novel virus, which was called Severe Acute respiratory Syndrome Coronavirus 2 (SARS- COV2) or 2019 novel Coronavirus (2019-nCoV). ${ }^{1}$ The infection extended throughout the world and WHO declared global pandemic. ${ }^{2}$ Social distancing is the most important preventive strategy. Many countries were forced to implement complete lockdown as controlling measures. Lockdown had been imposed all over India since $23^{\text {rd }}$
March, 2020. Though the country had started gradual withdrawal of lockdown, the educational institutions remained closed.

Medical education in India has undergone a dramatic transformation from didactic lectures to team-based learning and early clinical exposure over the last decade. ${ }^{3}$ Undergraduate medical education is now emphasising on competency-based teaching, case/ clinical scenario-based teaching, small group learning, and hands-on practical/ clinical exposure. ${ }^{4}$ These newly designed teaching and learning strategies have been unexpectedly disrupted by COVID-19 pandemic. $^{5}$ 
The burden of huge syllabus and uncertainty of extension of present session made the medical faculties to continue the teaching-learning session using different online system. This online learning has also impact on boosting up the morale of medical students by creating a diversion from the ongoing pandemic situation. However, its practicability and productivity are yet to be explored. Therefore, online survey was designed to explore the feasibility and efficacy of online teaching-learning methodology adopted in different medical colleges of West Bengal among medical students in this study.

\section{MATERIALS AND METHODS}

Forty-four validated questions in English language in the Google form were distributed among the undergraduate MBBS students of different medical colleges of West Bengal only using different social media groups in this cross-sectional study, following the 'CHERRIES' guidelines. ${ }^{6}$ The study was approved by the Institutional Ethics committee. Survey questionnaire was composed of general enquiry regarding demography, academic activities during pre and ongoing pandemic periods, the problems faced by the students to adapt themselves with this new technique, their level of satisfaction, status of course completion and their suggestions.

Descriptive analysis and comparison of normally distributed data were analysed by Student's t-test using PSPP v1.4.1.

\section{RESULT}

\section{Demographic information}

Four hundred sixteen students (male-215, female-201) from both urban (242) and rural (174) areas participated in this online survey. The mean age of the participants was $20.9 \pm 1.6$ yrs. Maximum number of respondents were of $1^{\text {st }}$ Professional MBBS batch $(198,48 \%)$ followed by $2^{\text {nd }}$ Professional MBBS (96, 23\%), final MBBS part-I (72, 17\%) and final MBBS part-II (50, 12\%).

Responses were received from 16 out of 20 medical colleges of West Bengal. Only 54 participants attended online teaching methods in pre-COVID-19 pandemic era, while 401 (96.4\%) participated during the lockdown periods to continue teaching-learning process. Maximum number (372) of participants attended lecture classes, followed by 111 participants in demonstration classes, 51 in practical classes and 47 students in clinical classes. While 27 participants responded that all of the above-mentioned teaching learning methods are followed in their colleges, 15 students responded negatively. Only 47 (11.3\%) participants affirmed online classes regarding clinical exposure, which seems the most neglected section of MBBS curriculum during this pandemic. Year wise distribution of the data showed lowest number of clinical classes were organized for $2^{\text {nd }}$ year MBBS students $(3,3.13 \%)$ followed by final MBBS- part 2 students (5, 10\%) and final MBBS - part 1 students $(10,13.89 \%)$ whereas highest no of clinical classes $(29,14.65 \%)$ were conducted for $1^{\text {st }}$ year students.

Two hundred forty-five $(58.9 \%)$ participants responded that online classes were not conducted following a notified weekly routine, and $290(69.7 \%)$ students found difficulty in following online classes. Interestingly 342 (82.2\%) respondents took it positively to clarify their queries at the end of the classes. Ninety-one $(21.9 \%)$ participants felt that the pace of the online classes is same as that of the offline classes. However, 141 (34\%) students felt the pace of the online classes is faster, while $168(40.3 \%)$ respondents felt the pace is slower than the offline classes. Two hundred thirty-four $(56.3 \%)$ students reportedly suffered technical problems due to poor network connectivity. Few students felt that some teachers are not tech-savvy that caused inadvertent errors while attending classes. However, 202 (48.6\%) students responded that regular assessments were conducted by their Institutions, which is undoubtedly a positive approach in this pandemic era (Table 1).

Teaching hours are significantly reduced during this pandemic phase which was $5.5 \pm 1.9 \mathrm{~h} /$ day before lockdown when colleges were open and conventional offline classes were possible and $1.9 \pm 1.2 \mathrm{~h} /$ day during lockdown phase when online mode of teaching is the only possible way of delivering education.

\begin{tabular}{|c|c|c|c|}
\hline Questions & Yes & No & $\begin{array}{c}\text { No } \\
\text { answer }\end{array}$ \\
\hline $\begin{array}{l}\text { Were Online classes organised by } \\
\text { your college/department before } \\
\text { lockdown? }\end{array}$ & 54 & 359 & 3 \\
\hline $\begin{array}{l}\text { Is there any online teaching activity } \\
\text { conducted by your college during } \\
\text { this pandemic? }\end{array}$ & 401 & 15 & 0 \\
\hline $\begin{array}{l}\text { Are there any online classes } \\
\text { organised by your college regarding } \\
\text { clinical exposure? }\end{array}$ & 47 & 338 & 31 \\
\hline Is it difficult to follow online classes? & 290 & 126 & 0 \\
\hline $\begin{array}{l}\text { Are the faculties taking classes as } \\
\text { per fixed weekly routine? }\end{array}$ & 171 & 245 & 0 \\
\hline $\begin{array}{l}\text { Is there any doubt clearance } \\
\text { session during classes? Can you } \\
\text { ask questions during class? }\end{array}$ & 342 & 74 & 0 \\
\hline $\begin{array}{l}\text { Are regular assessments taken by } \\
\text { the departments? }\end{array}$ & 202 & 214 & 0 \\
\hline $\begin{array}{l}\text { Are you facing any technical/ } \\
\text { internet related problem while } \\
\text { attending online classes? }\end{array}$ & 234 & 182 & 0 \\
\hline
\end{tabular}




\section{Table 2: Participants view regarding curriculum activities}

\begin{tabular}{|c|c|c|c|c|c|}
\hline & 1 (Strongly disagree) & 2 (Disagree) & 3 (Neutral) & 4 (Agree) & 5 (Strongly agree) \\
\hline S1 & $76(18.26 \%)$ & $123(29.57 \%)$ & $152(36.54 \%)$ & $50(12.02 \%)$ & $15(3.61 \%)$ \\
\hline S2 & $76(18.26 \%)$ & $102(24.52 \%)$ & $137(32.93 \%)$ & $72(17.3 \%)$ & $29(6.99 \%)$ \\
\hline S3 & $228(54.8 \%)$ & $102(24.52 \%)$ & $57(13.7 \%)$ & $16(3.85 \%)$ & $13(3.13 \%)$ \\
\hline S4 & $193(46.39 \%)$ & $108(25.96 \%)$ & $75(18.03 \%)$ & $33(7.93 \%)$ & $7(1.69 \%)$ \\
\hline S5 & $54(12.98 \%)$ & $53(12.74 \%)$ & $114(27.4 \%)$ & $139(33.41 \%)$ & $56(13.47 \%)$ \\
\hline
\end{tabular}

S1 The online classes meet my expectation

S2 The THEORY syllabus will be/is completed within stipulated time frame

S3 The PRACTICAL syllabus will be/is completed within stipulated time frame

$\mathrm{S}_{4}$ The online classes are more effective than regular offline classes

$\mathrm{S}_{5}$ The online course learning should be combined with classroom learning in the future

Most participants believed that their theory classes could be completed within specified time frame, though completion of practical syllabus/clinical classes is questionable. Three hundred one $(72.3 \%)$ participants are of opinion that online classes are ineffective than the traditional offline classes, although a blended approach appeared to be quite acceptable to them (Table 2).

One hundred fifty-seven $(37.7 \%)$ respondents believe that the current session should be extended on an average of 3 months $(2.91 \pm 1.053$ months $)$ after reopening of the college for completion of the syllabus and hands-on training in practical or adequate training on clinics prior to the final university examination (Table 3).

\section{Technical information}

It is evident from the participant's response that $93 \%$ of them use their smartphone to follow the online classes. Though $38 \%$ of them possess laptop/desktop, only $13.7 \%$ use it to follow the online classes, and $92.3 \%$ of them uses mobile data. Though number of broadband users increased from $5.5 \%$ to $13.2 \%$ to have stable connectivity, but that may not be possible for the students residing at rural areas.

Online webinar is the most commonly used platform (74.7\%), followed by PowerPoint / PDF/ other e-learning material sharing in social networking groups / sites (64.9\%) including You tube video upload (33.65\%) and live video in social network sites (13.2\%). Zoom video platform and Google meet are the most preferred services to conduct online classes. Some $(42 \%)$ of them realized that this online based teaching system imposing financial burden to them.

\section{DISCUSSION}

The coronavirus pandemic has led to introduction of novel methods of delivering education to medical students. Lectures are delivered online as webinars using the various platforms such as Zoom Cisco WebEx and Google meet. Such technologically advanced approaches have been proven to have high level of engagement with medical students. ${ }^{7}$ Online teaching platforms are beneficial due

\begin{tabular}{|c|c|c|}
\hline \multicolumn{2}{|c|}{ Current session should be extended } & $\begin{array}{l}\text { Current session } \\
\text { should not be } \\
\text { extended }\end{array}$ \\
\hline $323(77.64 \%)$ & & $93(22.36 \%)$ \\
\hline $\begin{array}{l}157 \text { (Mentioned time) } \\
\text { (in month) } \\
2.91 \pm 1.053 \\
\text { (Mean } \pm S D \text { ) } \\
3 \text { (Median) }\end{array}$ & $\begin{array}{l}166 \text { (Not } \\
\text { mentioned time) }\end{array}$ & \\
\hline
\end{tabular}

to their worldwide accessibility, ensuring that all medical students regardless of their current location are able to access webinars as they happen. ${ }^{8}$

One study conducted at PGIMS, Rohtak among 200 MBBS students highlighted the problems like poor technology friendly teachers, lack of interactive teaching, easy distraction and technical issues. Continuous assessment, ward teaching, practical and clinical teaching are grossly deficient. Integrated teaching, which is the part of MBBS curriculum involving both the clinical and paraclinical aspects, are also missing. ${ }^{9}$

Another study conducted among 77 postgraduate medical students highlighted the online sessions are feasible, cheap and easily accessible alternative method of traditional classroom teaching. ${ }^{10}$ Online learning is a good alternative for MBBS international students when classroom learning is suspended, though it cannot replace the need for onsite and face-to-face learning similar to our findings. ${ }^{11}$

While "Live" patient contact is an irreplaceable tenet of clinical teaching, current pandemic situation demands exceptional measures. Pedagogical innovations involving technology and simulation-based teaching (video case vignettes, virtual simulators, webcasting, and recorded video demonstration) need to be brought to the forefront for better clinical and preclinical practical exposure. ${ }^{12}$

Student's internal and external development of emotional intelligence, situational awareness, and professional 
behaviours, as well as personal feelings of love and empathy is all catalysed in the hospital and college environment through the interactions with peers, teachers, technicians, academics, patients and their relatives. ${ }^{13}$

A study among 219 dental residents in 2014 showed low teacher-student interaction and student comfort in online live classes. They preferred watching recorded video lecture much more than live online classes. ${ }^{14} \mathrm{~A}$ recent study conducted at Bristol Medical School during this pandemic phase also infers the same. ${ }^{15}$

Challenges faced in this virtual mode of teaching includes - a) insufficient hand-on clinical/practical skill training, b) lack of proficient use of modern technology by the faculties and the students, c) poor student engagement due to lack of continuous attention in home atmosphere, multi-tasking while attending classes, internet related issues leading to frequent disconnection, poor audio and video quality etc, ${ }^{16} \mathrm{~d}$ ) excessive information from several online resources, ${ }^{17}$ e) deterioration of mental health due to absence of peer group support, less physical activity, isolation, anxiety associated with the pandemic situation, ${ }^{17,18}$ and f) difficulty in conducting valid online regular assessment.

It should be ensured that all sessions are recorded so that students can review the sessions at their convenience. It may be useful to have a central monitoring agency to develop pedagogically useful standardized learning content using web-based applications. ${ }^{12}$

Online classes of shorter duration, use of interactive tools during the classes like pop quizzes, poll, and use of virtual whiteboards can effectively engage the students during classes. ${ }^{16}$ Regular quality check by regular feedbacks from the students is necessary to assess the effectiveness of the online classes. ${ }^{19}$

\section{CONCLUSION}

While it may appear necessary online/ digital/simulationbased learning during contagious pandemic era; poor technical skills, poor network connectivity inadequate infrastructure and absence of institutional strategies are important barriers to cater the purpose. Though it is a suitable resort in the pandemic time, its use in regular course can be only supplementary, not even complementary.

\section{ACKNOWLEDGEMENT}

The authors take this opportunity to thank the students of different medical colleges of West Bengal for their whole hearted support for this study.

\section{Abbreviations}

nCoV, novel coronavirus; SARS-COV-2, Severe Acute respiratory Syndrome Coronavirus-2

\section{REFERENCES}

1 Das SK. The pathophysiology, diagnosis and treatment of corona virus disease 2019 (COVID-19). Indian J Clin Biochem. 2020; 35:385.

https://doi.org/10.1007/s12291-020-00919-0

2. Listings of WHO's response to COVID-19. (2020). Retrieved 20 September 2020, from https://www.who.int/news-room/ detail/29-06-2020-covidtimeline

3. Skochelak SE and Stack SJ. Creating the medical schools of the future. Acad Med. 2017; 92:16. https://doi.org/10.1097/ACM.0000000000001160

4. Ghosh A, Pal R and Kumar R. Competency-based medical education: How far, how much. J Family Med Prim Care. 2019; 8:2751.

https://doi.org/10.4103/jfmpc.jfmpc_680_19

5. Rose S. Medical student education in the time of COVID-19. JAMA. 2020; 323:2131.

https://doi.org/10.1001/jama.2020.5227

6. Eysenbach G. Improving the quality of Web surveys: The Checklist for Reporting Results of Internet E-Surveys (CHERRIES). J Med Internet Res. 2004; 6: e34.

https://doi.org/10.2196/jmir.6.3.e34

7. Kay D and Pasarica M. Using technology to increase student and faculty satisfaction with engagement in medical education. Adv Physiol Educ. 2019; 43:408.

https://doi.org/10.1152/advan.00033.2019

8. Sandhu $P$ and de Wolf $M$. The impact of COVID-19 on the undergraduate medical curriculum. Med Educ Online. 2020; 25:1764740.

https://doi.org/10.1080/10872981.2020.1764740

9. Verma A, Verma S, Garg P and Godara R. Online Teaching During COVID-19: Perception of Medical Undergraduate Students. Indian J Surg. 2020; 1. [published online ahead of print, 2020 Jun 27]

https://doi.org/10.1007/s12262-020-02487-2

10. Agarwal $S$ and Kaushik JS. Student's Perception of Online Learning during COVID Pandemic. Indian J Pediatr. 2020; 87:554.

https://doi.org/10.1007/s12098-020-03327-7

11. Zhang Q, He YJ, Zhu YH, Dai MC, Pan MM, Wu JQ, et al. The evaluation of online course of Traditional Chinese Medicine for MBBS international students during the COVID-19 epidemic period. Integr Med Res. 2020; 9:100449. https://doi.org/10.1016/j.imr.2020.100449

12. Sahi PK, Mishra D and Singh T. Medical Education Amid the COVID-19 Pandemic. Indian Pediatr. 2020; 57:652. https://doi.org/10.1007/s13312-020-1894-7

13. Franchi T. The impact of the Covid-19 pandemic on current anatomy education and future careers: a student's perspective. Anat Sci Educ. 2020; 13:312. https://doi.org/10.1002/ase.1966

14. Kunin M, Julliard KN and Rodriguez TE. Comparing face-toface, synchronous, and asynchronous learning: postgraduate dental resident preferences. J Dent Educ. 2014; 78:856. https://doi.org/10.1002/j.0022-0337.2014.78.6.tb05739.x 
15. Roberts V, Malone K, Moore P, Russell-Webster T and Caulfield R. Peer teaching medical students during a pandemic. Medical Education Online. 2020; 25:1772014.

https://doi.org/10.1080/10872981.2020.1772014

16. Kaup S, Jain R, Shivalli S, Pandey S and Kaup S. Sustaining academics during COVID-19 pandemic: The role of online teaching-learning. Indian J Ophthalmol. 2020; 68:1220.

https://doi.org/10.4103/ijo.IJO_1241_20

17. Dhir SK, Verma D, Batta M and Mishra D. E-learning in medical education in India. Indian Pediatr. 2017; 54:871. https://doi.org/10.1007/s13312-017-1152-9

18. Mishra D, Nair AG, Gandhi RA, Gogate PJ, Mathur S, Bhushan P, et al. The impact of COVID-19 related lockdown on ophthalmology training programs in India - Outcomes of a survey. Indian J Ophthalmol. 2020; 68:999. https://doi.org/10.4103/ijo.IJO_1067_20

19. O'Doherty D, Dromey M, Lougheed J, Hannigan A, Last J and McGrath D. Barriers and solutions to online learning in medical education - An integrative review. BMC Med Educ. 2018; 18:130. https://doi.org/10.1186/s12909-018-1240-0

Author's Contribution:

BS- Concept and design of the study; collected data and prepared first draft of manuscript; MH- Reviewed the literature and manuscript preparation; MM- Statistically analysed and interpreted; SKD- Statistically analysed and interpreted, preparation of manuscript and revision of the manuscript.

Work Attributed to:

College of Medicine and JNM Hospital, Kalyani, West Bengal, India.

Orcid ID:

Dr. Bhaskar Saha- iD https://orcid.org/0000-0002-9274-3711

Dr. Mrityunjoy Halder- (1) https://orcid.org/0000-0001-5755-4467

Dr. Mita Mandal- it https://orcid.org/0000-0003-4359-821X

Dr. Subir Kumar Das- https://orcid.org/0000-0003-0908-5437

Source of Funding: None, Conflict of Interest: None 